\title{
Timber-Concrete Composite Ribbed Slabs with High-Performance Fibre-Concrete
}

\author{
Karina Buka-Vaivade \\ department of Structural Engineering \\ Riga Technical University \\ Riga, Latvia \\ Karina.Buka.Vaivade@gmail.com \\ Andrejs Podkoritovs \\ department of Structural Engineering \\ Riga Technical University \\ Riga, Latvia \\ Andrejs.Podkoritovs@gmail.com
}

\author{
Dmitrijs Serdjuks \\ department of Structural Engineering \\ Riga Technical University \\ Riga, Latvia \\ Dmitrijs.Serdjuks@rtu.lv \\ Raimonds Ozolins \\ department of Structural Engineering \\ Riga Technical University \\ Riga, Latvia \\ Raimonds.Ozolins@rtu.lv
}

\author{
Janis Sliseris \\ department of Structural Engineering \\ Riga Technical University \\ Riga, Latvia \\ Janis.Sliseris@rtu.lv
}

Abstract - Composite of such renewable material as timber and the most popular man-made material as concrete offers many benefits. Such of them are high load-bearing capacity with low dead load and increased structural bending stiffness. Higher specific strength of high-performance concrete in comparison with ordinary concrete ensures more efficient use of the material. Addition of fibres can reduce the fragility and autogenous shrinkage cracks of highperformance concrete and makes it possible to design thinner layers of concrete for timber-concrete composite structures. Ribbed slabs as solution for the floor slabs, allows to reduce material consumption and to integrate engineering communications into the structures. The current study focuses on determining the effect of the use of highperformance fibre reinforced concrete for timber-concrete composite ribbed slabs with adhesive connection between layers, as the most effective connection type for composite action. The effect of the use of high-performance fibre reinforced concrete is determined by comparison of midspan displacements of the ribbed slabs numerical models. Three-dimensional finite element models of timber and ordinary concrete composite ribbed slab and highperformance fibre reinforced concrete with additional longitudinal reinforcement ribbed slab are validated by experiment data. Developed numerical models makes it possible to predict the dependence of applied load on midspan displacement in three-point bending with sufficient precision. Obtained results showed, that replacement of ordinary concrete layer by high-performance fibre reinforced concrete in timber-concrete composite ribbed slab with adhesive connection up to 1.68 times decrease vertical mid-span displacements.
Keywords - finite element method, high-performance fibrereinforced concrete, ribbed slab, timber-concrete composite, wood-concrete composite.

\section{INTRODUCTION}

Timber is a renewable material what makes the significant advantage for it use in construction. Concrete is the most widely used man-made building material. Timberconcrete composite (TCC) structures can ensure more efficient use of resources and meet the growing demand for sustainable structures.

Combining such two materials as timber and concrete, can improve various classic disadvantages of wooden floors, such as dynamic reaction, bending stiffness, loadbearing capacity, sound insulation [1] - [3], structural fire safety - the effective cross-sectional area increases as timber member is subjected to the fire action from one side [4], [5], seismic performance [6] and heat mass. The natural frequency of the structure [7] is also important. Timberconcrete slabs allow to achieve such dynamic design parameters that ensure their safe operation for rhythmic activities [2].

As high-performance concrete is characterized by higher specific strength in comparison with ordinary strength concrete, its use in structures is more rational. Disperse reinforcement can reduce the fragility of highperformance concrete [8] - [10], which makes it possible to design thin layers and improve the fire safety of the material. The ribbed slabs allow to reduce material

\footnotetext{
Online ISSN 2256-070X

https://doi.org/10.17770/etr2021vol3.6551

(C) 2021 Karina Buka-Vaivade, Dmitrijs Serdjuks, Janis Sliseris, Andrejs Podkoritovs, Raimonds Ozolins. Published by Rezekne Academy of Technologies. This is an open access article under the Creative Commons Attribution 4.0 International License.
} 
consumption and the dead load of structures, as well as to integrate engineering communications into the structures.

Studies approve that the use of fibre-reinforced concrete in TCC structures with notch connections or shear mechanical connectors increases the shear strength of structure [11] - [13]. From the point of view of structure strength and stiffness, adhesive connections are the best solution that can ensure almost perfect performance of the composite material.

The structural solution offered by the composite of timber and high-performance fibre reinforced concrete (HPFRC) ribbed slabs is actual and complies with the principles of sustainable construction. So, the aim of this study is to determine the effect of using HPFRC instead of ordinary concrete (OC) layer in TCC ribbed slab with the adhesive connection between materials.

\section{MATERIALS AND METHODS}

A ribbed slab subjected to the three-point bending was considered as an object of this investigation. Influence of HPFRC in TCC ribbed slab with rigid connection between materials layers on mid-span displacements was evaluated by finite element (FE) numerical model. All numerical models were developed with structural analysis program RFEM by solid elements. For timber-based elements 3D orthotropic elastic material model was used. For the concrete type elements 3D isotropic Mazars' damage material model was used with non-linear stress-strain diagrams. For 3D numerical model of the TCC specimens contact solid between concrete and plywood layers is defined with full force transmission. Target length of FE equal to $0.0075 \mathrm{~m}$ and 200 load increments was used for TCC model, $0.02 \mathrm{~m}$ and 100 was used for HPFRC ribbed slab model.

Two laboratorian experiments were carried out to validate the used numerical modelling procedure of TCC member and HPFRC material behaviour. The aim of the numerical modelling procedure validation is comparison of the specimen behaviour with actual operation and checking of developed model safety.

The first laboratorian experiment was necessary to validate TCC slab three-dimensional (3D) numerical model by small-scale specimens. The four specimens of TCC ribbed slabs were made with $\mathrm{C} 24$ strength class timber boards with dimensions $67 \mathrm{x} 43 \mathrm{~mm}$ for slabs ribs, $30 \mathrm{~mm}$ OC layer with strength of C20/25 class and $9 \mathrm{~mm}$ plywood layer. PVA D3 was used for timber boards and plywood layer gluing. The adhesive connection between concrete and plywood layers are made by gluing $16-25 \mathrm{~mm}$ granite chips on plywood by epoxy Sikadur-31 CF [14], [15]. After that concrete layer was placing on granite chips. Total length of the specimens was $600 \mathrm{~mm}$, with effective span $430 \mathrm{~mm}$. Cross-section and design scheme of the timberconcrete ribbed slab specimen is shown in Fig.1.

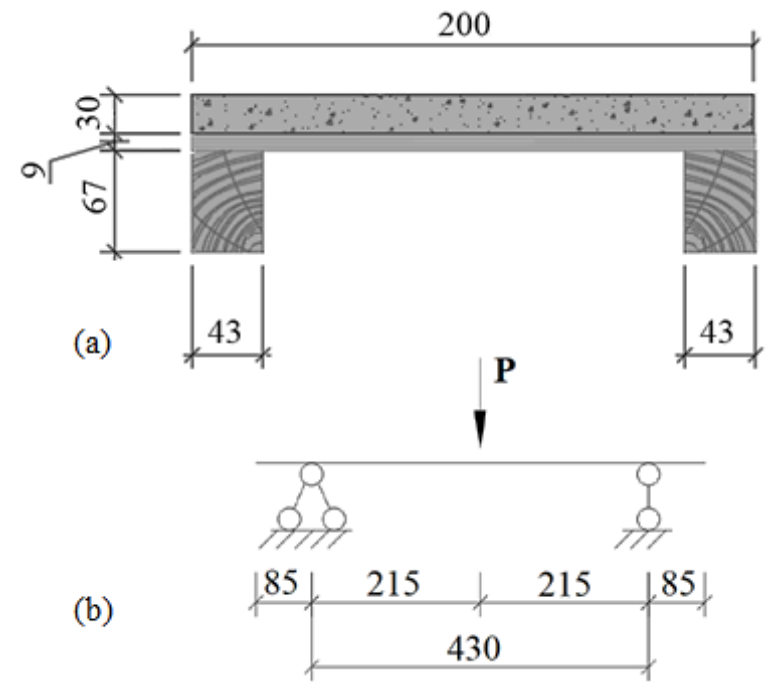

Fig. 1. TCC ribbed slab specimen (a) cross-section, (b) design scheme.

The second laboratorian experiment was necessary to determine the accuracy of prediction of high-performance fibre reinforced concrete ribbed slab non-linear behaviour by 3D numerical model within degradation of modulus of elasticity cause of cracking.

The specimen of HPFRC ribbed slab was free supported slab with span $1.23 \mathrm{~m}$. The geometric dimensions and loading scheme of HPFRC specimen is shown in Fig.2. Each rib has B500 steel longitudinal bar with diameter of $6 \mathrm{~mm}$. Polypropylene (PP) Strux 90/40 fibres in amount of $0.5 \%$ of the concrete volume were used. For $40 \mathrm{~mm}$ long fibres with an aspect ratio of 90, the tensile strength is $620 \mathrm{MPa}$, the modulus of elasticity - 9.5 GPa and the elongation - 10\%. Compressive strength of cube specimen with dimensions $10 \times 10 \times 10 \mathrm{~cm}$ from highperformance synthetic macro fibres reinforced concrete, according to compressed cube tests, was determined as 92.5 MPa. The following parameters of HPFRC were used for calculations: $78 \mathrm{MPa}$ compressive strength, 4.6 $\mathrm{MPa}$ tensile strength and $41 \mathrm{GPa}$ modulus of elasticity.

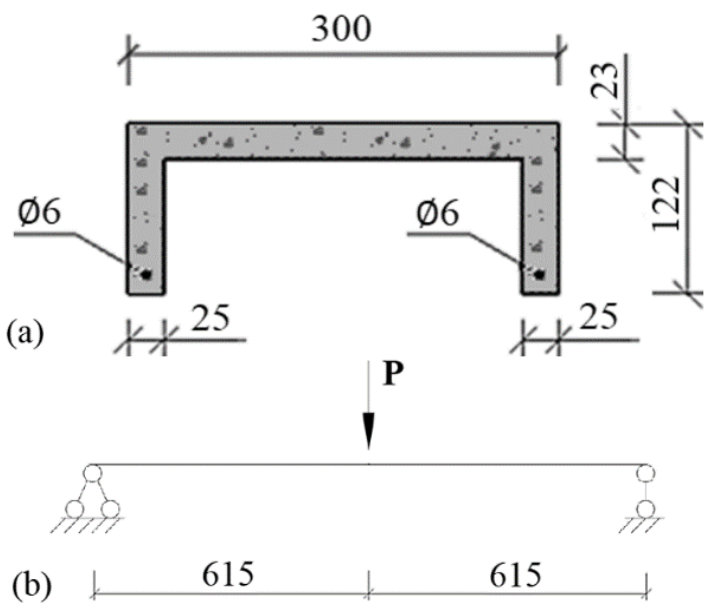

Fig. 2. HPFRC ribbed slab specimen (a) cross-section, (b) design scheme. 
Environment. Technology. Resources. Rezekne, Latvia Proceedings of the $13^{\text {th }}$ International Scientific and Practical Conference. Volume 3, 40-44

With the aim of determining the effect of the use of HPFRC in TCC ribbed slab 3D model with the same dimension as timber-concrete composite ribbed slab was developed by replacing ordinary concrete layer with HPFRC.

\section{RESULTS AND DISCUSSION}

Load-displacement curves of TCC ribbed slab specimen in three-point loading, according to laboratory testing as average result of four specimens testing and numerical model calculations, are summarized in Fig.3. First cracks in timber was heard at load level equal about $25 \mathrm{kN}$, at load level about $55 \mathrm{kN}$ the concrete layer cracked, average crashing load of the slabs was about $61.25 \mathrm{kN}$ [16]. According to the results obtained (Fig.4.), distribution of maximal stresses calculated by 3D numerical model corresponds to the nature of the collapse of the TCC ribbed slab with ordinary concrete layer. As it can be seen from load-displacement curves of TCC ribbed slabs, linear elastic stage is until about $40 \mathrm{kN}$, after what elastic-plastic stage is started. According to the laboratory test, mid-span displacement of the TCC ribbed slab at the load level equal to $40 \mathrm{kN}$ is $4.42 \mathrm{~mm}$, while the calculated by 3D non-linear numerical model corresponding displacement is $4.81 \mathrm{~mm}$.

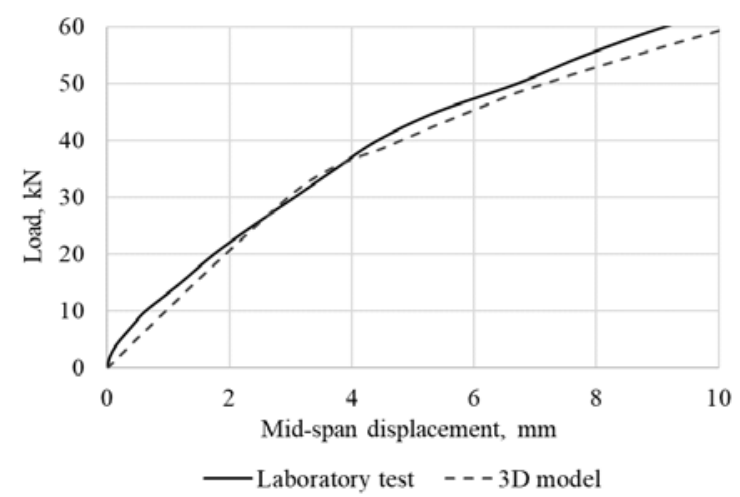

Fig. 3. Load-displacement curves for TCC ribbed slab specimen.
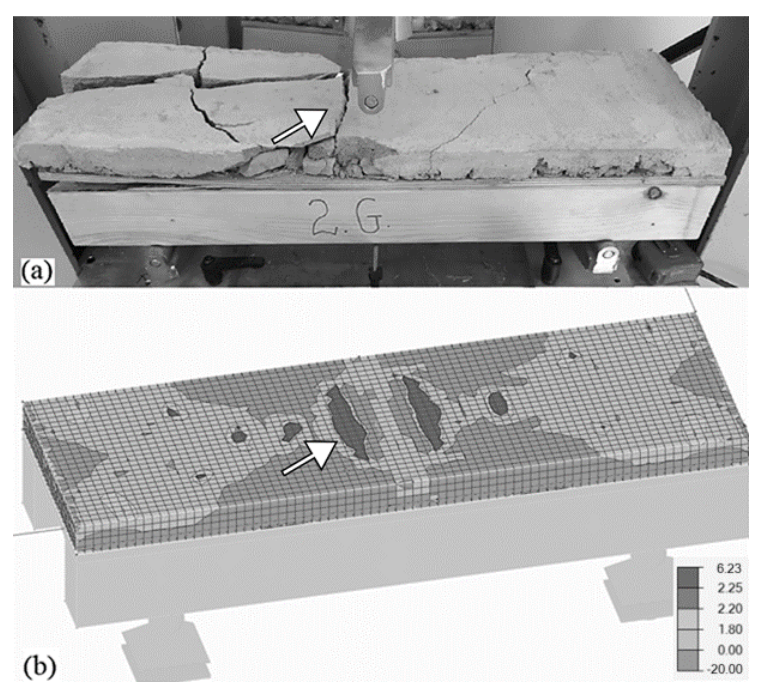

Fig. 4. OC layers of TCC ribbed slab (a) collapse and (b) corresponding stress distribution.
In elastic-plastic stage 3D model produces little more conservative results of the behaviour of the TCC ribbed slab subjected to the three-point bending than data obtained by the experiment. The curve obtained with the 3D model very accurately describes the behaviour of the specimen.

Load-displacement curves of HPFRC ribbed slab specimen in three-point loading, according to laboratory testing and numerical model calculations, are summarized in Fig.5. Experimental maximal load for ribbed slab was $15.42 \mathrm{kN}$ with corresponding mid-span displacement 10.16 $\mathrm{mm}$. Results obtained by numerical model showed, that starting with the load level of $14.65 \mathrm{kN}$ with corresponding displacement $10.08 \mathrm{~mm}$, load increasing by $1 \%$ increased displacements by $8.3-22 \%$. The behaviour of the calculation model at the linear stage is identical to the actual operation of the HPFRC ribbed slab specimen. The linear stage of load-displacement curve is until about 4.28 $\mathrm{kN}$ with corresponding mid-span displacement equal to $0.34 \mathrm{~mm}$, after what elastic-plastic stage is started. In elastic-plastic stage 3D model produces more conservative results of the behaviour of the HPFRC ribbed slab subjected to the three-point bending than data obtained by the experiment.

As it can be seen in Fig.6., distribution of maximal stresses calculated by 3D numerical model corresponds to the nature of the collapse of the HPFRC ribbed slab. It can be concluded, that developed model is safe for prediction of the behaviour of HPFRC material.

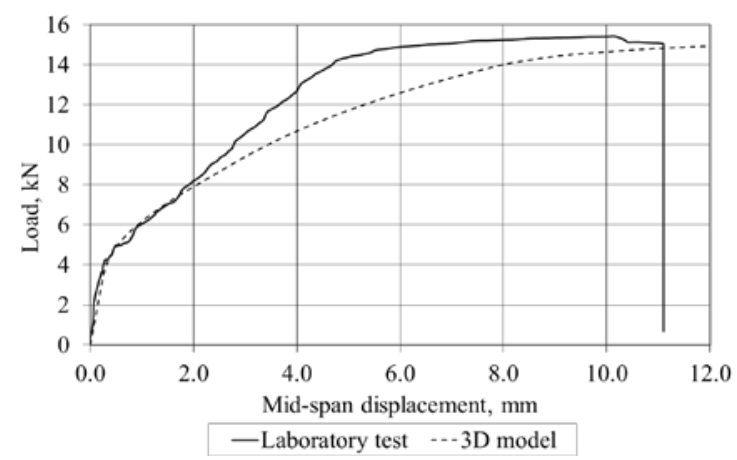

Fig. 5. Load-displacement curves for HPFRC ribbed slab specimen.
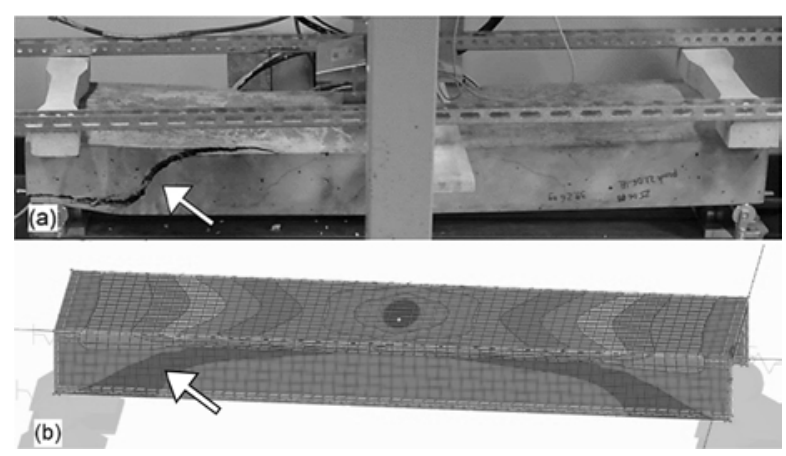

Fig. 6. HPFRC ribbed slab (a) collapse and (b) corresponding stress distribution. 


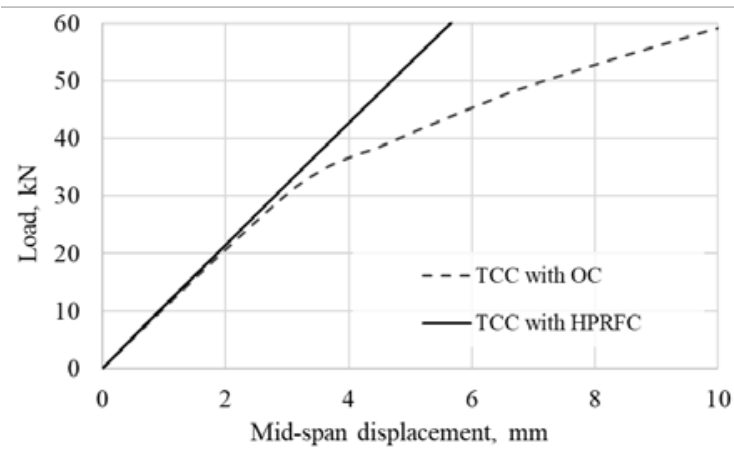

Fig. 7. Load-displacement curves for TCC ribbed slab specimens with OC or HPFRC obtained by numerical model.

The load-displacement curves of ribbed slab subjected to the three-point bending according to the developed 3D numerical models of TCC with OC and with HPFRC layer are enclosed in Fig.7.

As it can be seen from obtained curves, the character of the curves is the same up to about $22 \mathrm{kN}$. After these load level in the specimen with OC layer larger deformations begin to develop, but for specimen with HPFRC layer the dependence of the displacements on the load remains linear. So, on the $40 \mathrm{kN}$ load level, displacement obtained by 3D numerical model with HPFRC layer equal to the 3.73 $\mathrm{mm}$. At load level of $55 \mathrm{kN}$, when according laboratory test OC layer in TCC completely cracked, the mid-span displacement of the TCC ribbed slab with OC layer obtained by numerical model is $8.67 \mathrm{~mm}$, but displacement of the TCC ribbed slab with HPFRC layer is only $5.15 \mathrm{~mm}$.

On the load level of $61 \mathrm{kN}$ maximal tension stresses obtained by 3D numerical model of the TCC ribbed slab with OC layer is up to $6.23 \mathrm{MPa}$, at a tensile strength of OC 2.2 MPa. At the same load level maximal tension stresses obtained by 3D numerical model of the TCC ribbed slab with HPFRC layer is up to $5.18 \mathrm{MPa}$, at a tensile strength of HPFRC 4.6 MPa.

\section{CONCLUSIONS}

Numerical models of high-performance fibre reinforced concrete ribbed slabs and timber-concrete ribbed slabs with ordinary concrete layer were checked and showed adequate results. Developed models with sufficient precision describes the behaviour of the ribbed slabs subjected to the flexure. The difference in the mid-span displacement between calculated with developed numerical model and experimental results on the load level of linear-elastic stage is about $8.8 \%$ for the TCC ribbed slab with ordinary concrete layer. For high-performance fibre reinforced concrete ribbed slab almost identical mid-span displacements in the linear-elastic stage were obtained.

The use of high-performance fibre reinforced concrete instead ordinary concrete layer in timber-concrete ribbed slab increases energy absorption of the element. At the low load level to about $22 \mathrm{kN}$ there is no difference in behaviour of the both specimens with different concrete layers. At the load level, which according to the experiment corresponds to the linear-elastic stage end with the HPFRC layer it is possible to obtain at least 1.18 times less displacements than with ordinary concrete, and for load level of $55 \mathrm{kN}$, which correspond to complete cracking of the ordinary concrete layer, according to the numerical models, with the HPFRC layer it is possible to obtain 1.68 times less displacements of the TCC ribbed slab than with ordinary concrete layer.

Results of tensile stresses obtained by numerical models shows, that the specimen of the TCC ribbed slab with OC layer completely cracked, because tensile stresses exceeding the tensile strength of ordinary concrete by $183 \%$. At the same time, tensile stresses of the TCC ribbed slab with HPFRC layer exceeds the tensile strength by only $12.6 \%$, what means, that cracking in this specimen are only in initial stage.

In future studies, it is planned to make specimens of TTC with the fibre reinforced concrete layer for laboratory testing to verify the results obtained by numerical modelling.

\section{ACKNOWLEDGMENTS}

This research was supported by Riga Technical University's Doctoral Grant programme and Latvian Council of Science funded project "Method of correlation of coaxial accelerations in 6-D space for quality assessment of structural joints (COACCEL)” (Nr. lzp-2020/1-0240).

\section{REFERENCES}

[1] J. Rodrigues, A. Dias and P. Providência, "Timber-concrete composite bridges: State-of-the-art review," BioResources, vol. 8, pp. 6630-6649, 2013. DOI: 10.15376/biores.8.4.6630-6649

[2] A. Dias, J. Skinner, K. Crews and T. Tannert, "Timber-concretecomposites increasing the use of timber in construction," European Journal of Wood and Wood Products, vol. 74, pp. 443 451, 2016. DOI: 10.1007/s00107-015-0975-0

[3] V. Bajzecerová, "Bending Stiffness of CLT-Concrete Composite Members - Comparison of Simplified Calculation Methods," Procedia Engineering, vol. 190, pp. 15-20, 2017. DOI: 10.1016/j.proeng.2017.05.301

[4] M. V. Gravit, D. Serdjuks, A. V. Bardin, V. Prusakov and K. Buka-Vaivade, "Fire design methods for structures with timber framework," Magazine of Civil Engineering, vol. 85, pp. 92-106, 2019. DOI: 10.18720/MCE.85.8

[5] J. Natterer, "A way to sustainable architecture by new technologies for engineered timber structures," Proceedings of the World Conference on Timber Engineering, 2004.

[6] P. Croce, M. Beconcini, P. Formichi, F. Landi and D. Cardella, "Fatigue behaviour of composite timber-concrete beams," Procedia Structural Integrity, vol. 11, pp. 363-370, 2018. DOI: 10.1016/j.prostr.2018.11.047

[7] M. N. Kirsanov, "Analytical assessment of the frequency of natural vibrations of a truss with an arbitrary number of panels," Structural Mechanics of Engineering Construc-tions and Buildings, vol. 16, pp. 351-360, 2020. DOI: 10.22363/1815-5235-2020-16-5-351360

[8] K. Buka-Vaivade, J. Sliseris, D. Serdjuks, L. Pakrastins and N. I. Vatin, "Rational use of HPSFRC in multi-storey building, " Magazine of Civil Engineering, vol. 84, pp. 3-14, 2018. DOI: 10.18720/MCE.84.1

[9] K. Buka-Vaivade, J. Sliseris, D. Serdjuks, G. Sahmenko and L. Pakrastins, "Numerical Comparison of HPFRC and HPC Ribbed Slabs," IOP Conference Series: Materials Science and Engineering, vol. 660, Nr. 012054, 2019. DOI: 10.1088/1757899X/660/1/012054

[10] J. Sliseris and K. Buka-Vaivade, "Numerical Modelling of High Strength Fibre-Concrete's columns in Multi-Storey Building," IOP 
Environment. Technology. Resources. Rezekne, Latvia Proceedings of the $13^{\text {th }}$ International Scientific and Practical Conference. Volume 3, 40-44

Conference Series: Materials Science and Engineering, vol. 660, Nr. 012062, 2019. DOI: 10.1088/1757-899X/660/1/012062

[11] K. Holschemacher and H. Kieslich, "Recent developments in timber-concrete composite," CLEM+CIMAD 2017, 2017.

[12] S. Lamothe, L. Sorelli, P. Blanchet and P. Galimard, "Engineering ductile notch connections for composite floors made of laminated timber and high or ultra-high performance fiber reinforced concrete," Engineering Structures, vol. 211, Nr. 110415, 2020. DOI: $10.1016 /$ j.engst

[13] K. Holschemacher, S. Klotz and D. Weisse, "Application of Steel Fibre Reinforced Concrete for Timber-Concrete Composite Constructions," Lacer, pp. 161-170, 2002.
[14] R. Vasiljevs, D. Serdjuks, J. Gerasimova, K. Buka-Vaivade and A. Orhun Erüz, "Behaviour of Timber-Concrete Joints in Hybrid Members Subjected to Flexure," IOP Conference Series: Materials Science and Engineering, vol. 660, Nr. 012050, 2019. DOI: 10.1088/1757-899X/660/1/012050

[15] R. Vasiljevs, D. Serdjuks, K. Buka-Vaivade, A. Podkoritovs and N. Vatin, "Load-carrying capacity of timber-concrete composite panels," Magazine of Civil Engineering, vol. 93, pp. 60-70, 2020. DOI: 10.18720/MCE.93.6

[16] V. Budovskis, "Analyse of load - currying capacity increase for timber subjected for flexure," M.S. thesis, Riga Technical university, Riga, Latvia, 2020 